\title{
Uji Efektifitas Ekstrak Etanol Bawang Batak terhadap Keputihan yang berlebihan pada Wanita Usia Subur
}

\author{
Iskandar Markus Sembiring ${ }^{1, *}$, Novidawati Boru Situmorang ${ }^{2}$ \\ ${ }^{1}$ Fakultas Keperawatan dan Fisioterapi (FKF), Institut Kesehatan Medistra Lubuk Pakam, Lubuk Pakam, 20512, Indonesia \\ ${ }^{2}$ Fakultas Farmasi (FF), Institut Kesehatan Medistra Lubuk Pakam, Lubuk Pakam, 20512, Indonesia \\ ${ }^{1}$ Email : iskandar_sembiring@ymail.com *; ${ }^{2}$ Email : novidawati@gmail.com; \\ * corresponding author
}

ARTICLE INFO

Keywords

Bawang batak

keputihan

wanita usia subur

\begin{abstract}
Batak onion plants contains flavonoids, triterpenoids, steroids, and saponins. Compounds that can inhibit bacterial growth are flavonoids. This type of research is a quantitative study using a true experimental research design (pure experiment) with a rancangan "pretest-posttes" model. Namely, before the treatment was carried out, observations were made on the sample and after the treatment was also carried out several observations. Collecting samples, making simplicia, making extraction by maceration using $96 \%$ ethanol solvent, making thick extracts with concentrations of $15 \%, 20 \%$ and $25 \%$. The effectiveness test was carried out in reducing excessive vaginal discharge by taking the vaginal discharge for women of childbearing age, then doing a $\mathrm{pH}$ test on the vaginal discharge and adding the ethanol extract of batak onions after that the $\mathrm{pH}$ test was again carried out. The results showed that the onion extract (Allium schoenoprasum L) concentrations of $15 \%, 20 \%$ and $25 \%$ were able to reduce excessive vaginal discharge in women of childbearing age and the results of vaginal $\mathrm{pH}$ examinations showed that the concentration of $25 \%$ was faster to stabilize vaginal $\mathrm{pH}$ which was too alkaline. For further researchers, it is recommended to formulate the ethanol extract of the onion hobo (Allium schoenoprasum L) into a solid soap or ovule preparation.
\end{abstract}

\section{Pendahuluan}

Bagi wanita satu hal yang terpenting dan butuh perhatian khusus adalah kesehatan reproduksi yaitu bagian organ intimnya (vagina) terutama dalam hal kebersihannya. Vagina sangatlah sensitif karena letaknya tersembunyi, tertutup dan terdapat flora normal (mikroorganisme) yang harus dijaga keseimbangannya. Jika hal ini tidak dapat dilakukan oleh wanita akan menimbulkan gangguan seperti keputihan (fluor albus) [1]. Di negara Indonesia sekitar 90\% wanita berpotensi mengalami keputihan dan sekitar 75\% wanita Indonesia ternyata pernah mengalami keputihan minimal satu kali dalam masa hidupnya dan $45 \%$ lainnya mengalami keputihan lebih dari dua kali bahkan lebih. Hal tersebut terjadi karena daerah Indonesia beriklim tropis, yang membuat jamur dan bakteri pathogen mudah tumbuh dan berkembang biak serta memicu tingginya kasus keputihan pada perempuan Indonesia. Efek yang timbul bermacammacam, diawali dengan pengeluaran lendir berwarna putih, kuning atau bahkan hijau sampai biru. Pengeluaran lendir ini juga disertai dengan rasa gatal pada kemaluan [2].

Jika keputihan dibiarkan, maka lama kelamaan daerah kemaluan menjadi berbau busuk dan nyeri yang sangat hebat akibat peradangan. Komplikasi yang lebih serius dapat terjadi penyakit seperti radang panggul, infeksi saluran telur, infertilitas, bahkan awal timbulnya pertumbuhan kanker serviks [3]. Infeksi jamur dan bakteri pathogen pada vagina atau dalam istilah medisnya disebut kandidiasis merupakan gangguan yang sering disebabkan oleh infeksi yang ditularkan melalui hubungan badan, pakaian dalam yang terlalu lembab dan kotor. Peradangan vagina tidak hanya diderita oleh wanita yang masih subur, tetapi juga bisa diderita oleh wanita yang telah mencapai usia menopause yang disebabkan oleh perubahan hormon setelah tidak menstruasi lagi [4]. 
Indonesia memiliki kekayaan tanaman yang beraneka ragam, khususnya di Sumatera Utara kaya akan tanaman seperti buah-buahan, sayuran dan bawang batak. Tanaman bawang batak banyak terdapat di dataran tinggi Berastagi, Sidikalang, Tapanuli, Deli Serdang dan daerah sekitarnya [4]. Salah satu genus tanaman yang banyak digunakan oleh masyarakat sebagai bumbu masakan adalah bawang batak. Masyarakat banyak yang tidak tahu bahwa bawang batak dapat dijadikan penghambat pertumbuhan mikroorganisme seperti bakteri, jamur, virus dan parasit $[5,6,7]$.

Bawang batak berpotensi sebagai aktivitas antijamur dan antibakteri maupun pengawet makanan serta mengandung senyawa seperti flavonoid, triterpenoid, steroid dan saponin. Kandungan senyawa flavonoid dan triterpenoid yg memiliki aktivitas antijamur dan antibakteri bisa digunakan sebagai antijamur yang disebabkan oleh candida albicans pada masalah kesehatan keputihan yang berlebihan, tetapi belum ada yang menguji efektifitas ekstrak etanol bawang batak untuk menghambat keputihan yang berlebihan [8]. Berdasarkan uraian di atas maka peneliti tertarik melakukan penelitian tentang "Uji Efektifitas Ekstrak Etanol Bawang Batak terhadap Keputihan yang berlebihan pada Wanita Usia Subur".

Rumusan masalah dalam penelitian ini adalah "Apakah Sediaan Ekstrak Etanol Bawang Batak dengan konsentrasi 15\%, 20\% dan 25\% efektif untuk menghambat keputihan yang berlebihan pada WUS?

Tujuan khusus penelitian ini adalah menguji efektifitas ekstrak etanol bawang batang dengan konsentrasi 15\%, 20\% dan 25\% untuk menghambat keputihan yang berlebihan pada WUS.

Urgensi penelitian bahwa Keputihan yang berlebihan harus semaksimal mungkin ditangani melalui cara tradisional yang tidak menimbulkan efek samping yang berbahaya. Jika tidak segera tangani, maka mengakibatkan masalah yang lebih serius seperti penyakit radang panggul, infeksi saluran telur, infertilitas, bahkan awal timbulnya pertumbuhan kanker mulut rahim/serviks.

\section{Metode}

Jenis penelitian ini merupakan penelitian kuantitatif dengan menggunakan desain penelitian true experiment (experiment murni) dengan model rancangan "pretest-posttes" yaitu sebelum dilaksanakannya perlakuan maka dilakukan observasi pada sample dan sesudah perlakuan juga dilakukan beberapa kali observasi [15].

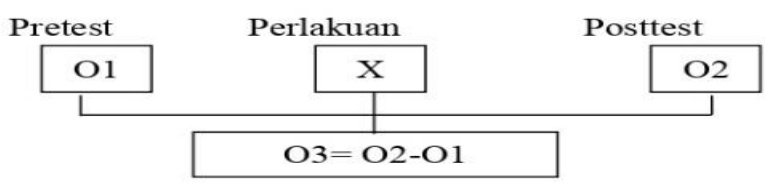

\section{Hasil dan Pembahasan}

\subsection{Hasil Ekstrak Bawang Batak}

Bawang batak sebanyak $5 \mathrm{~kg}$ basah, sebanyak $5 \mathrm{~kg}$ bawang batak dikeringkan. Simplisia direndam dalam etanol $96 \%$ dan diperoleh filtrat, kemudian filtrat dipektakan dengan rotary evaporator pada suhu $\pm 170^{\circ} \mathrm{C}$ sampai menghasilkan ekstrak pekat, kemudian ekstrak pekat di uapkan dengan water bath dengan suhu $\pm 70^{\circ} \mathrm{C}$ sampai menghasilkan ekstrak kental bawang batak dengan berat 36 gram. 


\subsection{Hasil Uji Efektifitas Ekstrak Bawang Batak}

\begin{tabular}{|c|c|c|c|c|c|c|c|}
\hline \multirow[t]{3}{*}{ Responden } & \multirow{2}{*}{\multicolumn{3}{|c|}{$\begin{array}{l}\text { Sebelum uji } \\
\text { Konsentrasi }\end{array}$}} & \multirow{2}{*}{\multicolumn{3}{|c|}{$\begin{array}{l}\text { Sesudah uji } \\
\text { Konsentrasi }\end{array}$}} & \multirow{3}{*}{$\begin{array}{l}\text { Persyaratan } \\
\text { pH normal }\end{array}$} \\
\hline & & & & & & & \\
\hline & $15 \%$ & $20 \%$ & $25 \%$ & $15 \%$ & $20 \%$ & $25 \%$ & \\
\hline 1 & 6,5 & 6,5 & 6,5 & 5 & 4,5 & 4 & $3,8-4,5$ \\
\hline 2 & 7 & 7 & 7 & 5,8 & 5 & 4,5 & $3,8-4,5$ \\
\hline 3 & 6,8 & 6,8 & 6,8 & 5,8 & 4,8 & 4 & $3,8-4,5$ \\
\hline 4 & 6 & 6 & 6 & 4,5 & 4 & 3,8 & $3,8-4,5$ \\
\hline 5 & 6 & 6 & 6 & 4,8 & 4 & 3.8 & $3,8-4,5$ \\
\hline 6 & 8 & 8 & 8 & 6,5 & 5,5 & 4,5 & $3,8-4,5$ \\
\hline 7 & 7 & 7 & 7 & 4,8 & 4 & 3,8 & $3,8-4,5$ \\
\hline 8 & 7,8 & 7,8 & 7,8 & 6,8 & 4,8 & 4 & $3,8-4,5$ \\
\hline 9 & 6,5 & 6,5 & 6,5 & 4,5 & 4 & 3,5 & $3,8-4,5$ \\
\hline 10 & 6 & 6 & 6 & 4 & 3,5 & 3 & $3,8-4,5$ \\
\hline 11 & 6,8 & 6,8 & 6,8 & 4,8 & 4 & 3,2 & $3,8-4,5$ \\
\hline 12 & 6,8 & 6,8 & 6,8 & 5,5 & 4,5 & 4 & $3,8-4,5$ \\
\hline 13 & 7,5 & 7,5 & 7,5 & 6 & 4,8 & 3,8 & $3,8-4,5$ \\
\hline 14 & 7,8 & 7,8 & 7,8 & 6 & 5,5 & 4 & $3,8-4,5$ \\
\hline 15 & 7 & 7 & 7 & 5,5 & 4,5 & 3,5 & $3,8-4,5$ \\
\hline 16 & 7 & 7 & 7 & 5,8 & 4 & 3,8 & $3,8-4,5$ \\
\hline 17 & 8,5 & 8,5 & 8,5 & 6,5 & 5,5 & 4,5 & $3,8-4,5$ \\
\hline 18 & 8 & 8 & 8 & 7 & 5,8 & 4,8 & $3,8-4,5$ \\
\hline 19 & 6,5 & 6,5 & 6,5 & 4,8 & 3,8 & 3 & $3,8-4,5$ \\
\hline 20 & 6 & 6 & 6 & 5 & 4,5 & 3,5 & $3,8-4,5$ \\
\hline 21 & 7 & 7 & 7 & 5,5 & 4,8 & 4,2 & $3,8-4,5$ \\
\hline 22 & 6,8 & 6,8 & 6,8 & 4,8 & 4 & 3,5 & $3,8-4,5$ \\
\hline 23 & 7,8 & 7,8 & 7,8 & 6 & 5,5 & 3,8 & $3,8-4,5$ \\
\hline 24 & 7 & 7 & 7 & 5,8 & 4,8 & 3,8 & $3,8-4,5$ \\
\hline
\end{tabular}

Berdasarkan hasil pengukuran nilai $\mathrm{pH}$ sebelum dilakukan uji efektifitas ekstrak etanol bawang batak diperoleh nilai pada responden 1-24 sebelum pengujian $\mathrm{pH}$ cairan vagina responden tinggi/basa setelah di lakukan uji maka $\mathrm{pH}$ cairan vagina responden mengalami perubahan yang berbeda-beda setiap konsentrasi,dimana $\mathrm{pH}$ cairan vagina responden menjadi menurun/mengarah asam. Dapat dilihat perubahannya dari $\mathrm{pH}$ sesudah dilakukan uji pada konsentrasi 25\% lebih signifikan menurunkan angka pH cairan vagina yang artinya konsentrasi $25 \%$ lebih efektif untuk mengurangi keputihan berlebihan pada wanita usia subur.

Lactobacillus merupakan bakteri dominan didalam vagina. Peran tersebut dilakukan dengan memproduksi asam laktat untuk menjaga keasaman $\mathrm{pH}$ vagina serta memproduksi hydrogen peroksida yang berperan dalam menekan pertumbuhan bakterbakteri lain dalam vagina. Peranan Lactobacillus dianggap sangat penting untuk menjaga keseimbangan ekosistem vagina dan menekan pertumbuhan mikroorganisme pathogen karena mempunyai kemampuan untuk mengubah glikoge dari epitel vagina yang terlepas menjadi asam laktat, sehingga vagina tetap dalam keadaan $\mathrm{pH}$ asam $(\mathrm{pH} 3,0-4,5) \cdot \mathrm{pH}$ asam inilah yang mencegah pertumbuhan mikrooganisme yang pathogen [6]. 


\subsection{Hasil Uji Efektivitas Ekstrak Etanol Bawang Batak Terhadap keputihan pada wanita usia subur dinilai dari nilai diameter zona hambat}

Hasil uji efektivitas ekstrak bawang batak dapat dilihat pada tabel berikut ini.

\begin{tabular}{|c|l|c|c|c|c|}
\hline No & \multirow{2}{*}{$\begin{array}{c}\text { Konsentrasi ekstrak bawang batak } \\
(\%)\end{array}$} & \multicolumn{3}{|c|}{ Diameter Zona Hambat } & \multirow{2}{*}{$\begin{array}{c}\text { Rata- } \\
\text { Rata }\end{array}$} \\
\cline { 3 - 5 } & & I & II & III & \\
\hline 1 & DMSO (Control negative) & - & - & - & - \\
\hline 2 & $15 \%$ & 12,10 & 12,14 & 12,15 & 12,13 \\
\hline 3 & $20 \%$ & 13,61 & 13,62 & 13,64 & 13,62 \\
\hline 4 & $25 \%$ & 14,30 & 14,31 & 14,32 & 14,31 \\
\hline
\end{tabular}

Keterangan: $(-)=$ tidak menghambat

$$
(\%)=\text { konsentrasi } \%(\mathrm{mg} / \mathrm{ml})
$$

Berdasarkan hasil pengukuran diameter zona hambat jamur Candida albicans, memperlihatkan bahwa ekstrak etanol bawang batak efektif dalam menghambat jamur tersebut. Menurut Depkes RI (2010), diameter daya hambat yang dinilai efektif yaitu diameter hambat lebih kurang 14-16 mm. Menurut Puji (2015), diameter zona hambat 5-10 mm dikategorikan lemah dan zona hambat antijamur yang paling efektif terhadap uji antijamur adalah 14-16 mm. menurut Siti dkk (2015), diameter zona hambat $5 \mathrm{~mm}$ dikategorikan lemah, diameter zona hambat 14 sampai $20 \mathrm{~mm}$ dikategorikan kuat dan diameter diatas $20 \mathrm{~mm}$ dikategorikan sangat kuat. Ekstrak etanol bawang batak menghambat pertumbuhan jamur Candida albicans pada konsentrasi 25\% dengan diameter zona hambat sebesar 14,31 mm. konsentrasi hambat minimum jamur Candida albicans pada konsentrasi $15 \%$ dengan diameter zona hambat 12,13 mm. Aktivitas suatu zat antimikroba dalam menghambat pertumbuhan atau membunuh mikroorganisme tergantung pada konsentrasi antimikroba tersebut [7].

\section{Kesimpulan}

Dari hasil nilai PH yang didapat ekstrak etanol bawang batak konsentrasi $15 \%, 20 \%$ dan $25 \%$ mampu mengurangi keputihan berlebihan pada wanita usia subur. Dan konsentrasi yang lebih efektif untuk mengurangi keputihan berlebihan pada wanita usia subur adalah kosentrasi $25 \%$.

Demikian juga dengan nilai zona hambat, Aktivitas antijamur pada konsentrasi $15 \%$ dengan diameter zona hambat $12,13 \mathrm{~mm}$, pada konsentrasi $20 \%$ dengan diameter zona hambat 13,62 mm dan yang mempunyai aktivitas antijamur terhadap jamur Candida albicans yang paling efektif pada konsentrasi 25\% dengan diameter zona hambat 14,31\%. 


\section{Ucapan Terima Kasih}

Terima kasih kepada Kementerian Pendidikan dan Kebudayaan (KEMENDIKBUD) dan kepada Lembaga Layanan Pendidikan Tinggi Wilayah I (LLDIKTI) serta Desa Talapeta Kecamatan STM Hilir Kabupaten Deli Serdang. Dengan adanya bantuan dari semua pihak, penelitian ini dapat berlangsung dengan baik semoga hasil penelitian ini dapat bermanfaat untuk masyarakat khususnya para wanita usia subur yang mengalami keputihan yang berlebihan.

\section{Referensi}

[1] Manuaba, dkk. 2009. Memahami Kesehatan Reproduksi Wanita. Jakarta: EGC

[2] Nurul, dkk. 2011. Kajian Faktor Threat dan Coping terhadap Partisipasi Wanita.

[3] Kurniawati, E. 2012. Aplikasi teori Healt Belief Model dalam Pencegahan keputihan Patologis, jurnal Promkes, (2), No.2

[4] Frans, G. N., Maria B., dan Fachriyan H.P. 2015. Antimicrobial Activity of Allium chinense G. Don. Jurnal Current Biochemistry Vol. 2 (3): 129-138. Diakses pada tanggal 20 Agustus 2018.

[5] Hussein, H. J., Hameed, I. H., \& Hadi, M. Y. (2017). A Review: Anti-microbial, Antiinflammatory effect and Cardiovascular effects of Garlic: Allium sativum. Research Journal of Pharmacy and Technology, 10(11), 4069-40786] E. Husanah, "Asuhan Kebidanan Pada Ny P Dengan Masalah Produksi ASI Melalui Terapi Kurma,” J. Komun. Kesehat., vol. XI, no. 1, 2020.

[6] Ikegbunam, M., Ukamaka, M., \& Emmanuel, O. (2016). Evaluation of the antifungal activity of aqueous and alcoholic extracts of six spices. American Journal of Plant Sciences, 7(1), 118125

[7] Diba, A., \& Alizadeh, F. (2018). In vitro and in vivo antifungal activity of Allium hirtifolium and Allium sativum. Avicenna journal of phytomedicine, 8(5), 465.

[8] Kyung, K.H. 2012. Antimicrobial Properties of Allium species. Current Opinion in Biotechnology. 23:142-147.

[9] Winaris, I.W. 2010. Menstruasi dan Keputihan. Dalam: 100 Tanya Jawab Masalah Kesehatan Untuk Remaja. Jogjakarta: Tunas Publishing, 163-198. WHO, 2010. Adolescent health. Available from: http://www.who.int/topics/ado lescent_health/en/. [Diakses 19 Agustus 2018].

[10] Bahari, Hamid. 2012. Cara Mudah Atasi Keputihan. Jogjakarta: Buku Biru

[11] Ellya, Eva, dkk. 2010. Kesehatan Reproduksi Wanita. Jakarta: CV Trans Info Media.

[12] Almunadia. 2016. Uji Aktivitas Antibakteri Ekstrak Etanol dan Fraksi-fraksi Daun Beluntas (Pluchae indica (L) Less) Terhadap Bakteri Escherichia coli dan Bacillus subtilis. Skripsi. Medan. Fakultas Farmasi Universitas Sumatera Utara

[13] Dinda, A.H. 2013. Uji Aktivitas Ekstrak Terimpang Bilalo (Actinopyga mauritiana (Quoy) Gaimard) Terhadap Jamur Candida albicans. Skripsi. Medan. Fakultas Farmasi Universitas Sumatera Utara.

[14] Grace, E.M.L. 2015. Potensi Ekstrak Umbi Bawang Lokio (Allium chinense G. Don) Dalam Menghambat Escherichia coli dan Meningkatkan Masa Simpan Ikan Nila (Oreochromis niloticus L). 
[15] Jahani, S. Bazi, S. Shahi, Z. Sheykhzade, A. 2017. Antifungal Effect Of the Extract of the Plants Against Candida albicans. Departement of Biologi, Faculty of Sciense, Payame Noor University, Iran.

[16] Zhang, T. Yu, dkk. 2015. 'Anticancer Activity Of Saponins From Allium chinense Againts The B16 Melanoma And $4 T 1$ Breast Carcinoma Cell' evidence-Based Complementary and Alternative Medicine. Hindawi Publishing Corporation. Available at : http//dx.doi.org/10.1155/2015/725023

[17] Arikunto. 2014. Prosedur penelitin suatu pendekatan praktek. Jakarta : Rineka Cipta

[18] Lachowicz, S., Kolniak-Ostek, J., Oszmiański, J., \& Wiśniewski, R. (2017). Comparison of phenolic content and antioxidant capacity of bear garlic (Allium ursinum L.) in different maturity stages. Journal of food processing and preservation, 41(1), e12921.

[19] Ren, F., Perussello, C. A., Zhang, Z., Gaffney, M. T., Kerry, J. P., \& Tiwari, B. K. (2018). Enhancement of phytochemical content and drying efficiency of onions (Allium cepa L.) through blanching. Journal of the Science of Food and Agriculture, 98(4), 1300-1309.

[20] Sugiyono. 2014. Metode Penelitian Pendidikan. Bandung: Alfabeta.

[21] Barus, B., \& Lestari, I. (2018). PENGARUH EKSTRAK UMBI BAWANG PUTIH DAN UMBI BAWANG MERAH TERHADAP LUKA BAKAR PADA KELINCI. JURNAL FARMASIMED $\quad(J F M), l(1), \quad 1-5 . \quad$ Retrieved https://ejournal.medistra.ac.id/index.php/JFM/article/view/86

[22] Departemen Kesehatan RI. (2013). Riset Kesehatan Dasar (Riskesdas) 2007: Laporan Nasional 2013. Jakarta: Badan Penelitian dan Pengembangan Kesehatan Depkes RI.

[23] William N Dunn, (1998), Pengantar Analisis Kebijakan Publik, Gajah Mada University Press, Yogyakarta.

[24] Baedah, M., St.Ratnah., Salasa,M,A., 2019. Formulasi Sabun Cair Ekstrak Daun Kecombrang Sebagai Anrikeoutihan. Media Farmasi p.issn 0216-2083 e.issn 2622-0962 Vol XV No 2.

[25] Departemen Kesehatan Republik Indonesia., 1995. Farmakope Indonesia Edisi IV, Direktorat Jendral Pengawasan Obat dan Makanan, Jakarta.

[26] Departemen Kesehatan Republik Indonesia., 2000. Parameter Standar Umum Ekstrak Tumbuhan Obat, Direktorat Jendral Pengawasan Obat dan Makanan, Jakarta. Hal 1-12; 13-37; 56-58.

[27] Dragon., St.Ratnah., Salasa,M,A., 2019. Formulasi Sabun Cair Ekstrak Daun Kecombrang Sebagai Atikeputihan. Media Farmasi p.issn 0216-2083 e.issn 2622-0962 Vol XV. No.2.

[28] Dr. Sari, W. M.Kes., dr.Irdrawati, L. M.Kes., Drs. Harianto, D,B. M.M., 2012. Panduan Lengkap Kesehatan Wanita, Cet 1, Penerbit Plus+, Jakarta. Hal 82-83.

[29] Fatmawati., Fahmi, A., Sitompul, H., 2019. Uji Aktivitas Antibakteri Salmonella thypii Dari Ekstrak Etanol Daun Bawang Batak (A. Chinenese G. Don), Universitas Efarina Pematang Siantar.

[30] Fera., Zumrotul, U., Liuensi, F, D., 2018. Pengaruh Penggunaan Air Rebusan Daun Sirih Hijau (Piper betle L) Terhadap Flour albus Pada Wanita Usia Subur di PMB AFAH FAHMI, Amd.KEB, Surabaya. Infokes Vol 8 No 2.

[31] Fera., 2016. Pengaruh Penggunaan Air Rebusan Daun Sirih Merah Terhadap Keputihan Pada Wanita Usia Subur (WUS) Di Wilayah Kerja Puskesma Rawat Inap Tenayan Raya, Diakses 05 Agustus 2019. 
[32] Ghina., Nadya., Tika., Ekstrak dan Identifkasi Senyawa. https//ccrc.farmasi.ugm.ac.id/?p=5323 (Diakses pada tanggal 8 Maret 2017) UGM Farmasi.

[33] Razak, A., Evasriningsih., 2017. Uji Daya Hambat Ekstrak Daun Kucai (Allium schoenoprasum L) Terhadap Pertumbuhan Streptococcus mutans, Jurnal Mandala Pharmacon Indonesia Vol 3. No 2.

[34] Harbone, J, B., 1987. Metode Fitokimia Penentuan Cara Modern Menganalisis Tumbuhan, Institut Teknologi Bandung, Bandung.

[35] Harbone, J, B., 1996. Metode Fitokimia. Institut Teknologi Bandung, Bandung

[36] Hasairin., 2014. Variasi Keunikan dan Ragam Makanan Adat Etnis Batak Toba Suatu Kajian Prospek Etnobotani, Jurnal Pengabdian Kepada Masyarakat, Vol 20 No 75 tahun XX.

[37] Kusmiran., Eny., 2013. Kesehatan Reproduksi Wanita, Jakarta: Salemba Medika.

[38] Kusmiran., Zumrotul, U., Liuensi, F, D., 2018. Pengaruh Penggunaan Air Rebusan Daun Sirih Hijau (Piper betle L) Terhadap Flour albus Pada Wnita Usia Subur di PMB AFAH FAHMI, $A, M D$. KEB. Surabaya Infokes Vol 8 No 2.

[39] Kyung, K, H., 2012. Antimicrobial Properties of Allium Spesies, Current Opinion In Biotecnology. 23;142-147.

[40] Lily., Rohmah., 2018. Formulasi Sediaan Sabun Cair Ekstrak Daun Sirih Hijau Piper betle L) dan Ekstrak Bawang Putih (Alliun sativum L) Sebagai Antijamur Candida albicans. Pharmaspa, Vol 2 No 2.

[42] Lestriani, I, S., 2016. Pengaruh Pemberian Minuman Kunyit Putih Terhadap Keputihan Pada Remaja Putri Usia 19-20 tahun, Penelitian Ilmiah. STIKes Ngudia Husada Madura.

[43] Munthe, G, N., Sembiring, M, I., Siregar, W, W., 2019. Pengaruh Konsumsi Bawang Batak Terhadap Keputihan Pada Wanita Usia Subur. Jurnal Kebidana Kasta (JKK) Vol 2 No 1.

[44] Naibaho, F, G., Maria, B., Fachriyan, HP., 2015. Antibacterial Activity of Allium chinense G Don, Curr-Biochem, 2(3); 129-139.

[45] Robinowich, HD and Currah L., 2002. Allium Crop Science; Recent Advences. New York; CABI Publishing.

[46] Royal Botanic Gardens. World Cdhecklist of Selected Plant Families, Diakses tanggal 18 Maret 2014.

[47] Seragih, D., Dyah., 2014. Tumbuhan Obat Untuk Mengatasi Keputihan, Jakarta; Rineka Cipta.

[48] St.Ratnah., Salasa, M, A., 2019. Formulasi Sabun Cair Ekstrak Daun Kecombrang Sebagai Antikeputihan, Media Farmasi p.issn 0216-2083 e.issn 2622-0962 Vol 2 XV No 2.

[49] Suprayanto., 2014. Wanita Usia Subur, dr-suprayanto.blogspot.com/2011/10/wanita-usiasubur-wus.html?m=l

[50] Tiwari, P., Kumar, B., Kaur, M., Kaur, H., 2011. Phytochemical Screening and Ekstraktion: A Review. Journal Internasional Pharmaceutical Sciencia. Vol 1:p 103-104. 
[51] Zumrotul, U., Liunesi, F, D., 2018. Pengaruh Penggunaan Air Rebusan Daun Sirih Hijau (Piper betle L) Terhadap Flour albus Pada Wanita Usia Subur di PMB AFAH FAHMI, Amd.KEB, Surabaya. Infokes Vol 8 No 2.

[52] 2015.Keputihan (Flour albus) Pada Remaja Indonesia, Jakarta: EGC.

[53] Wikipedia,2016. https://id.wikipedia.org/wiki/Berkas:Bawang batak.jpg. Diakses pada tanggal 26 februari 2016

[54] Willy, Tjin 2020. Menopause. https://www.alodokter.com/menopause. Diakses pada tanggal 22 April 2020 